\title{
Lost in Plain Sight: Rediscovering the Library of Sir Hans Sloane
}

\author{
Alison Walker
}

Sir Hans Sloane, physician, scientist, collector, President of both the Royal College of Physicians and the Royal Society, left his collections to the nation. They became the foundation of the British Museum (вM), and hence of its daughter institutions, the Natural History Museum (NHM) and the British Library (BL). Among the varied collections listed after his death in 1753, printed books constituted the single largest category, estimated at about 45,00o volumes. ${ }^{1}$ Yet today, although most of his books are at the B L and they may be in plain sight', individually if painstakingly locatable among other early printed material in the bookstacks, his library cannot be seen as a whole. One cannot go to the B L and simply see Sloane's library. This is because its identity was lost early in the history of the $\mathrm{BM}$, and subsequent events have led to the partial disperal of the collection and the loss, in many cases, of the marks which confirm Sloane's earlier ownership. This article will describe how the Sloane Printed Books project has gone about rediscovering Sloane's books, and to what extent there may indeed be 'lost books'.

The first step towards invisibility was when the Trustees of the BM received the library in 1757 and immediately re-arranged it. The books, they said, were "dispos'd in a very irregular manner, with little regard to the subjects or even the size of them", and directed that they should be "placed on the shelves according to their respective faculties", in other words, by subject. ${ }^{3}$ In Sloane's lifetime the books had been arranged principally by size, which makes the Trustees' comments rather puzzling, but also by format and genre, and probably largely set

1 A list of Sloane's collections, transmitted to his executors after his death in 1753 , is given by Arthur MacGregor, 'The life, character and career of Sir Hans Sloane', in Arthur MacGregor (ed.), Sir Hans Sloane Collector, Scientist, Antiquary (London: British Museum Press, 1994), pp. 28-29.

2 See $<$ www.bl.uk/reshelp/findhelprestype/prbooks/sloaneprintedbooksproject/sloaneprinted .html $>$ and $<$ www.bl.uk/catalogues/sloane $>$.

3 вм Archives (Trustees' Committee minutes) CE3/1. 117-121, quoted by F. J. Hill, 'The shelving and classification of printed books', in Philip R. Harris (ed.), The Library of the British Museum (London: British Library, 1991), p. 4. 
out to fit into the spaces designated for the book collection in his homes, first in Bloomsbury and later at Chelsea. This may explain why the arrangement could have seemed 'irregular' to the Museum's Trustees.

Once in the Museum, Sloane's books were rearranged by subject, and at first kept together in designated rooms at Montagu House, the Museum's first home. ${ }^{4}$ However, as the British Museum Library (BML) grew, it was decided in the 1780 s to rearrange the whole collection by subject. The move to the new Museum building after 1840 prompted a further reclassification, which remains the basic structure of the oldest parts of the BL printed books collection. Sloane's books now sit mingled with books from the Old Royal Library, the collections of Sir Thomas Birch, Sir William Musgrave, Sir Paul Methuen, Thomas Tyrwhitt, Major Arthur Edwards, Sarah Sophia Banks and various other purchases and donations. It must be recognised that the Museum was not generally in the practice of keeping acquisitions from particular owners together until the late eighteenth century, so Sloane's collection was not alone in being dispersed within the BML. Despite the fact that some of the collections mentioned above were given a distinctive security stamp and in some cases a binding stamp, they too had lost identity because the volumes were not placed together. Sloane's books did not at this time receive a special binding stamp, and the knowledge of how to identify his books seems to have been lost or at least gone underground for a long time. ${ }^{5}$ Little attempt seems to have been made to retain manuscript marks or other evidence of his ownership. The very manuscript catalogue which Sloane had used for his library was not known: not until the 1960 os was it rediscovered and recognised for what it was. ${ }^{6}$

Sloane's books, therefore, were lost in the sense that they were not identified, recognised or valued for their provenance. Further loss was occasioned by the widespread programme of rebinding which was applied to the early вML collections. ${ }^{7}$ A calf binding with a Museum identification stamp, usually incorporating the initials мв for Museum Britannicum, was generally used. In most cases all leaves before and after the text were removed and replaced with new endpapers. It seems that the bindings of many Sloane books had been in poor

4 Sloane's books were initially placed in rooms 4-11. Philip R. Harris, 'Identification of printed books acquired by the вм', in Giles Mandelbrote and Barry Taylor (eds.), Libraries within the Library (London: British Library, 2009), p. 405.

5 In the mid-1970s a stamp was designed for use when Sloane books were rebound, based on the stamp used for binding Sloane manuscripts, and continued in use until about 2004.

6 See below, notes 13 and 14 .

7 Philip R. Harris, A History of the British Museum Library (London: British Library, 1998), pp. 18-19, notes that in $175^{8}$ the estimated cost of rebinding and lettering Sloane books was $£ 246$, more than for either the Royal Library or the legal deposit books. 
condition, and large numbers received 'Museum Britannicum' bindings. At the same time, some economies were made by binding thin items together into tract volumes, or simply placing pamphlets in boxes, a process which would further disperse and relocate Sloane's books and pamphlets. Inevitably, much provenance information was lost. The marks which identify Sloane's books were particularly vulnerable, as they were often written on the pastedowns or blank endleaves.

The early collections also suffered significant loss from dispersal through the вм's sales of duplicate books between 1769 and $1832 .{ }^{8}$ The process of classifying the foundation collections had revealed large numbers of apparent duplicates, though in many cases we might not now see them as such since we are much more aware of copy-specific features in hand-press books. But the BM needed funds for new acquisitions, to the extent of often choosing to sell copies with coloured plates or attractive bindings which would reach higher prices, while retaining plainer or uncoloured copies. This practice certainly had an effect on the fate and survival of Sloane's natural history books. In these sales, copies from the earlier collections were often disposed of, and more recently acquired ones retained: thus in the 1818,1830 and $183^{1}$ sales, copies from the library of George III (the King's Library) and the library of Sir Joseph Banks, both of which reached the BM in the early nineteenth century, were often retained in preference to Sloane's copies. ${ }^{9}$ The King's and Banks copies may also have been valued for being generally fresher and less heavily used.

The number of Sloane books disposed of in the duplicate sales is unknown but was certainly substantial. ${ }^{10}$ Many, of course, have now found safe homes in other collections and libraries, but others may not have survived. Finally, with the founding of the Natural History Museum (NHM) in 1881, the natural history collections were separated out, and as part of the process many of Sloane's natural history books, including a coloured and annotated copy of his own

8 Thomas A. Birrell, 'The вм duplicate sales 1769-1832 and their significance for the early collections' in Mandelbrote and Taylor (eds.), Libraries within the Library, pp. 244-26o.

9 For example, Sloane's copy of Mark Catesby, The Natural History of Carolina, Florida and the Bahama Islands (London, 1731-1748) was sold by the Museum as a duplicate in 1818, while the copies from the libraries of C.M. Cracherode, Joseph Banks and George III were kept. Sloane's copy is now in the library of the Zoological Society of London.

10 A copy of the 1769 sale catalogue marked with the provenance of the items sold (Sloane, Old Royal Library, Birch, etc.) is held by the BL, C.191.a.56, but no such information is available for the subsequent sales, though they all contained considerable numbers of Sloane books. 
Voyage to Jamaica, were moved to South Kensington, where they were in due course further dispersed within the various departmental libraries. ${ }^{11}$

The early history of the BML explains why Arundell Esdaile, its first great historian, would write in 1943:

There is little that can be said about the library of Sir Hans Sloane.... The books have been mixed up with the later acquisitions which formed the Old Library, i.e. up to the middle of the nineteenth century, by the successive shelf-arrangements. Sloane's Ms press-marks by which they can be identified have only recently been traced. Nor is there a printed catalogue; but there is an incomplete one in manuscript.... There is no doubt that quantities of so-called duplicates were sold [from Sloane's library] in the sales up to $1805 .{ }^{12}$

This was a pretty accurate assessment at the time, but much has been done to shed light on Sloane's library since then. A crucial finding by Jeremiah Finch, an American scholar, was published in The Library in $1941 .^{13}$ Finch had been working on the library of Sir Thomas Browne, and his investigations into the catalogue of its sale had led him not only to work out that certain alphanumeric numbers found on the catalogue and on some of Browne's books were Sloane's marks, but to confirm the identity of one of the volumes of Sloane's own manuscript library catalogue, Sloane MS $3972 \mathrm{C}$. The remaining volumes of the catalogue seem to have been located in $1964 .{ }^{14}$ Sloane's library was re-emerging from obscurity, and library staff, including Margaret Nickson and Laurence Wood, began ground-breaking work on the books and manuscripts, in particular the decipherment of Sloane's purchase codes..$^{15}$ Sloane's manuscripts had

11 A Voyage to the Islands Madera, Barbados, Nieves, S. Christophers, and Jamaica, with the natural history...of the last of those islands; to which is prefixed an introduction wherein is an account of the inhabitants...trade, etc. (London, 1707-1725). Sloane's copy, with copious ms notes about specimens, and references to his Horti Sicci collections, is in the Botany Library at NHM. It has no British Museum stamp, which suggests that it was used in conjunction with his collection of specimens, rather than being treated as part of the BML.

12 Arundell Esdaile, The British Museum Library (London: George Allen \& Unwin, 1946), p. 177 .

13 Jeremiah S. Finch, 'Sir Hans Sloane's Printed Books', The Library, 22.1 (1941), pp. 67-72.

14 According to a note written by J.L. Wood in a photostat copy of Sloane MS 3972C, vol. III.

15 Margaret A.E. Nickson, 'Hans Sloane, book collector and cataloguer', British Library Journal, 14 (1988), pp. 52-89; Margaret A.E. Nickson, 'Books and Manuscripts', in MacGregor (ed.), Sir Hans Sloane, pp. 263-277; J.L. Wood, 'Sir Hans Sloane's books', Factotum, 2 (1978), pp. 15-18. 
fared rather better than the books in escaping disperal and disposal, being kept together as a collection although no longer in the numerical order that Sloane had used. The systematic identification of Sloane's printed books started in the 1970 , as interest in the library's named special collections began to increase, and it was realised how little was understood about the content of his library.

The BL now hosts the Sloane Printed Books Project and its catalogue of Sloane's books (SPBC). ${ }^{16}$ The database was first created in MSWord and then MSAccess, and since 2008 has used a format designed in house for a number of specialist BL catalogues. When the database was first launched for public access in 2008, it contained 13,000 entries, the product of intermittent work over some 20 years by staff and interns. Funding from the Wellcome Trust between 2008 and 2011 provided an invaluable increase in resources, and the project now continues supported by two part-time former BL staff members. The catalogue now has over 32,000 entries. Bibliographical information derived from the BL's catalogue is supplemented by fields designed to analyse the collection in a variety of ways: it can be used to locate individual Sloane books, but also to search, for example, on place of publication, date and genre, and to perform range searches on Sloane shelf numbers. This facility allows a virtual re-creation of the library's arrangement, within which we can see how Sloane organised his books. The presence of manuscript notes and the names of previous owners are recorded, revealing much information on the libraries from which Sloane acquired his books.

As mentioned above, Sloane's books are now scattered throughout the older part of the BL's collections. The main method we have used to identify Sloane's books is by shelf searches in the Old Library (shelfmark ranges 433-1467) which retains the subject classification devised by Thomas Watts (the 'elastic system') in the ${ }^{1840 s .} .^{17}$ It is relatively easy to pinpoint areas where clusters of Sloane books are likely to be found, such as medicine, natural history and philology, these being the strengths of his collection. Most of the British Library's early medical books are Sloane's. Not for nothing was his library described by a visitor in 1729 as "the most complete in Europe for books on medicine".18 Natural history too was a great strength of Sloane's library, though the number of his books still in the BL has been reduced by the overlap with Banks's library and subsequent duplicate disposals, and by the transfers to the Natural History Museum.

$16<$ www.bl.uk/catalogues/sloane>.

17 Harris, The British Museum Library, pp. 194-195.

18 Described by Sauveur Morand. Quoted in Arthur MacGregor, 'The life, character and career of Sir Hans Sloane', in MacGregor (ed.), Sir Hans Sloane, pp. 11-44, appendix 2: Sloane's Museum at Bloomsbury, as described by Sauveur Morand, 1729, p. 31. 
When we check the shelves, each book is examined for the distinctive marks that Sloane used and for the presence of the octagonal black Museum Britannicum stamp which marks his books, but which, sadly for us, continued in use on later acquisitions for some years. ${ }^{19}$ Sloane's mark is normally an alphanumeric, such as c 3606 or A 293 , which was probably used by Sloane as a shelf number, though no shelflist survives which might confirm this. ${ }^{20}$ Other manuscript notes, for example a note addressing the work to Sloane, may be used as identification. Even if Sloane's marks have been lost through rebinding or physical damage, the presence of the black stamp means that the book was probably Sloane's, and it is entered in the database as such. Even though we have now moved well beyond the obvious areas outlined above, we find Sloane books in many other categories: there are surprising numbers in theology, philosophy and biography, for example, though very few literary works.

It might have seemed more obvious to use the inverse process, by searching Sloane's own catalogues. After the discovery of the manuscript catalogue, there had been attempts to do this, but it is quite time-consuming, as there are often several copies of each book, each of which might have to be examined. In addition, there are considerable benefits of looking at each copy systematically on the shelf, allowing us to record evidence of provenance, manuscript notes, and significant bindings. Recently, however, we have started to work from the manuscript catalogues, and it is by collating the catalogues with the database that we are likely to turn up 'lost' copies, where an entry in the catalogue cannot be matched up with any of the BL's copies.

Sloane had several library catalogues. The first was started in 1684, and continued in use until 1686 . This is now Sloane Ms 3995, a small notebook containing a simple listing of bibliographical details and the price paid, with a running total of Sloane's expenditure. Then there is a catalogue hiatus, during the time when Sloane undertook his formative journey to Jamaica in 1687-1688, returned to London, and set up in practice as a physician. Around 1692 he started again, using the two separate catalogues for his books which would

\footnotetext{
19 The stamp used for Sloane's books is illustrated in Philip R. Harris, 'Appendix I: Identification of printed books acquired by the British Museum, 1753-1836', in Mandelbrote and Taylor (eds.), Libraries within the Library, p. 417.

20 Illustrations of Sloane's alphanumerics and other identifying marks can be found in the introduction to the Sloane Printed Books Catalogue online: <www.bl.uk/catalogues/ sloane>. Generally, a lower case letter is used for octavo or smaller volumes, and upper case for folio, but there are exceptions; for example $\mathrm{R}$ is used for octavo books, c and $\mathrm{G}$ both used for quartos. There are also special categories such as Min, for works with coloured illustrations, Pr for books with uncoloured images, Pr Or for oriental books, and Maps. The letter is followed by a running number, usually in order of acquisition.
} 
continue in use until his death. The six-volume manuscript catalogue now Sloane Ms $3972 \mathrm{C}$ and its two-volume index Sloane MS $3972 \mathrm{D}$ is the principal listing. ${ }^{21}$ Similar manuscript catalogues of Sloane's natural history and object collections are held at the вм and Nнм..$^{22}$ Separately, an interleaved copy of Lindenius renovatus, the medical bibliography by Joannes Antonides van der Linden revised by Georg Mercklein in 1686, was used by Sloane to record his medical books in Latin. ${ }^{23}$

Sloane MS $3972 \mathrm{C}$ was begun about 1692 , and used continuously until $175^{2}$. Entries were made both by Sloane himself and by the assistants who helped to catalogue the collection. It starts by listing books he already owned, thus there is some repetition of the entries in Sloane MS 3995, and then books were entered as they were acquired, filling up his alphanumeric sequences. Additional sequences were later brought in for books with engravings (using the alphanumeric Pr with a Roman numeral), books and manuscripts with coloured plates (alphanumeric Min with an Arabic numeral), periodicals, maps and Oriental material.

By the mid-169os Sloane had sufficient income from his profession and through his wife's inheritances to buy regularly at book sales, probably attending many in person; he used sale catalogues as bibliographies and sources, and was generally active, selective and creative in building his collection. He was also weeding out duplicates, particularly medical texts. Many were given to the Bodleian Library at this time, with the assistance of Humphrey Wanley. Books continued to be donated to the Bodleian until the $1730{ }^{24}$ Over 800 of these have been identified, though he is said to have given more than 1,400 volumes, so there may be many more yet to find. It is very probable that many of our 'lost' books, listed in Sloane MS $3972 \mathrm{C}$ but no longer at the BL, may in fact have been transferred there and remain to be discovered.

21 Nickson, 'Hans Sloane, book collector'. Amy Blakeway, 'The Library Catalogues of Sir Hans Sloane: Their Authors, Organization, and Functions', Electronic British Library Journal, <http://www.bl.uk/eblj/2011articles/article16.html>.

22 'Sir Hans Sloane's catalogues', in MacGregor (ed.), Sir Hans Sloane, pp. 291-294.

23 Joannes Antonides van der Linden, Lindenius renovatus, sive J. van der L....de scriptis medicis libri duo: ... addita plurimorum authorum...vitce curriculorum succincta descriptione: ... continuati, ...amplificati, ...et...purgati a G. A. Mercklino (Nuremberg, 1686). BL 878.n.8. This interleaved copy is not normally made available, but it may be consulted on microfilm.

24 William Poole, 'The Duplicates of Hans Sloane in the Bodleian Library: A detective story, with some comments on library organisation', Bodleian Library Record, 23 (2010), pp. 192-213. 
In general, Sloane Ms $3972 \mathrm{C}$ is an effective catalogue, with accurate bibliographical records. However, it is not an author catalogue, but is in accession order, supplemented by an author index. The index was apparently written up about 1723 from an earlier version, and added to, not always in alphabetical order, as new authors entered the collection. Anonymous works may be entered under their subject, or under a word from the title. Confusingly, both the early volumes of Sloane $\mathrm{MS} 3972 \mathrm{C}$ and Lindenius include desiderata lists to which shelf numbers have been added later as the works were acquired, but inevitably leaving entries for books which were never bought: these then are not 'lost' from Sloane's collection since they were never there. ${ }^{25}$

The interleaved copy of Lindenius is not easy to use, for several different reasons. In its printed form it is arranged by author's first name, with a surname index. Sloane added his alphanumeric to the printed pages to record his copies, and on interleaved pages he added works and editions not in the original. There are two sets of interleaving which were used to record books not in the printed work, the first set probably used from the start, the second, on larger paper, probably dating to the 1720 s when space for new titles ran out. The printed text includes entries for the constituent parts of compilations or general collections, though Sloane does not continue this practice. This means that the same work may appear several times under the authors of its separate sections, and Sloane's amanuenses were not always consistent in attaching his shelf numbers in all the correct places. Sometimes it is very difficult to work out which edition a number applies to, either because of the print layout or because the two sequences of interleaving have separated additional editions from those listed in the source bibliography. Sloane's many hundreds of academic dissertations can be difficult to identify because they are often entered under the examiner (Praeses) rather than the candidate (Respondens), whereas the BL catalogue normally enters them under the candidate's name. However, since the respective roles of presider/examiner and candidate are not always clear, and cataloguing practice varies between institutions and has varied over time at the $\mathrm{BL}$, it is not surprising that this particular type of publication can cause difficulty. ${ }^{26}$

Most of these difficulties of bibliographical identification can be overcome with time and perseverance. The fact remains, however, that some books listed in Sloane's catalogues cannot now be found in the BL. They could be lost, but

25 Blakeway, 'The Library Catalogues of Sir Hans Sloane', pp. 13-18.

26 See for example, Hora est! On dissertations (Leiden: Universiteitsbibliotheek Leiden, 2005). Kleine publicaties van de Leidse Universiteitsbibliotheek Nr. 7, especially Joseph S. Freedman, 'Disputations in Europe in the early modern period', pp. 30-50. 
we should first look at the ways in which books are known to have left the collection, and where some of them are now to be found.

Sloane certainly disposed of books during his lifetime. Gifts of duplicates to the Bodleian have already been mentioned. It is very probable that other smaller personal gifts may have been made. The Royal College of Physicians is said to have been given duplicate works, though only a few have been found there as yet. ${ }^{27}$ However, the great majority of lost or unlocated Sloane books are those that were sold as duplicates by the BM in the sales held between 1769 and 1832 . The BL has a copy of the 1769 sale catalogue in which the originating collection has been noted, but for all the others, we do not know which of the books listed came from Sloane, and therefore cannot calculate how many of his books were sold. ${ }^{28}$

The eventual fate of вм duplicates often depended on who was buying at the date of the sale, and on the subsequent moves or dispersals of the buyers' collections. Some clusters of books have descended at one or more removes from the purchasers to their current homes in institutional libraries. Thus, for example, William Hunter (1718-1783), the anatomist, is known to have acquired at least seven Sloane books among the twenty-five lots purchased at the 1769 sale. ${ }^{29}$ Among these was the magnificent polyglot Bible edited between 1655 and 1657 by Bishop Brian Walton, for which Hunter paid twelve guineas. Under the terms of Hunter's will, his library and other collections remained in London for several years after his death for the use of his nephew, Dr Matthew Baillie (1761-1823), and finally in 1807 came to Glasgow University where they remain one of the best-known of the library's rare book collections. ${ }^{30}$

The 1788 sale included large numbers of Sloane's medical books and dissertations, many of them probably duplicates from within his collection. A notable buyer of this material was James Sims, President of the Medical Society of London (MSL), which acquired his private collection in 1800. A substantial part of the MSL collection was later deposited at the Wellcome Library, and bought by the Wellcome in 1984. The number of Sloane books bought by Sims at the 1788 sale now in the Wellcome collection may be several hundred. Several items from the remainder of the MsL collection were sold to a Canadian buyer and are now in the Fisher Library at Toronto, which has 12 Sloane books. ${ }^{31}$

\footnotetext{
27 Alexander Chalmers, General Biographical Dictionary (London, 1816), vol. xxviI, p. 69.

28 Birrell, 'The вм duplicate sales', p. 247.

29 Ibidem.

30 <http://www.gla.ac.uk/services/specialcollections/collectionsa-z/hunteriancollection/\#d .en.119689>.

31 Julianne Simpson, 'From London to Toronto: a case-study of the dispersal of Sloane's library', in A. Walker, A. Macgregor and M. Hunter (eds.), From Books to Bezoars, London: British Library, 2012, pp. 221-226.
} 
Similarly over half of the 24 Sloane books at Durham bequeathed by Martin Joseph Routh (1755-1854), patristics scholar and President of Magdalen College, Oxford, are from the 1788 duplicate sale. ${ }^{32}$ Also buying in 1788 was Luís Pinto de Sousa Coutinho, first Visconde de Balsemão, 1735-1804, the Portuguese ambassador. 19 Sloane books from his collection are now at the Oporto Public Library. Several are of Hispanic interest, others on natural history or public health. $^{33}$

The Royal Society was not apparently buying at the earliest duplicate sales, but was active at the 1830 and 1831 sales, picking up some remarkable scientific and travel books from Sloane's library, sent as duplicates after the King's Library and Sir Joseph Banks's collection had been received. These included Descartes Opuscula, 1701, a large paper copy of Newton's Principia, third edition 1726, and some stunning illustrated works: Govard Bidloo's Anatomia humani corporis (Amsterdam, 1685); a coloured copy of Eleazar Albin, A Natural History of Birds (London, 1731); Maria Sibylla Merian, Metamorphosis insectorum Surinamentium (Amsterdam, 1705), this last of particular interest because of manuscript annotations which appear to refer to a specimen collection.

Individual Sloane books are now found in libraries and private collections across the world, from California to New Zealand, and they still turn up on the market: the database records several examples from recent sales and booksellers' catalogues. Sloane books have been found in sixty different locations, and many more certainly await discovery. As one might expect, the great university libraries of North America have substantial numbers of Sloane books; for example Folger, Huntington and Yale. Many more probably remain unidentified in other collections, unrecognised because they rarely bear Sloane's name. It is worth noting that the conscientious cataloguer can sometimes be overready to identify provenance, as our Hans Sloane, who did not use a bookplate, has often been confused with another Hans Sloane or Sloane-Stanley (17391827), his great-nephew, who had a library and did use a bookplate. ${ }^{34}$ Booksellers and librarians alike have been caught in this trap.

$32<$ <ttps://www.dur.ac.uk/library/asc/collection_information/cldload/?collno=122>.

33 Júlio Costa, 'The Portuguese trail of the scientific and medical library of Hans Sloane: issues and evidences $=$ No rasto português da biblioteca científico-médica de Hans Sloane: problemas e evidências', PÁGINAS a\&b: arquivos e bibliotecas, 9 (2012), pp. 91-108.

34 The armorial bookplate with the name of 'Hans Sloane Esq.' was used on Sloane-Stanley's books, which seem to have been kept at the family home at Paultons, near Romsey, Hampshire, until the estate was sold in 1955, Roger Cyril Hans Sloane Stanley, Paultons. A catalogue of a valuable portion of the contents of the mansion formerly the property of Major R.C. Hans Sloane Stanley, etc. (Woolley \& Wallis, auctioneers.), ([Salisbury]: Bennett Bros., 1955). 
It may be a lengthy task to identify the books from Sloane's collection which have found their way into other libraries, but it is more or less achievable. Other types of publication are more intractable, and it is here that we are most likely to identify 'lost' material. Periodicals, ephemera and dissertations can prove elusive, each genre for its own particular reasons. Sloane had at least 53 separately identified periodical titles, ranging from London Bills of Mortality to the Journal des Sçavans. He normally gave periodicals a number and a volume number, separated by a colon, e.g. 4:13, rather than the alphanumeric used for books. Most numerous among these were the publications of the scientific societies which flourished across Europe in the early eighteenth century, which would naturally fall within the scope of Sloane's library. However, many of Sloane's periodicals have disappeared, possibly discarded as incomplete runs or sold as duplicates in favour of the more complete sets acquired with the King's Library and Sir Joseph Banks's collection. Possibly the greatest loss is the Royal Society's Philosophical Transactions: the BL no longer has Sloane's set of the journal of which he was editor, and which surely would have significant association value or possible annotations.

Newspapers are even more elusive. It seems probable that Sloane had some newspaper titles, but the only substantial run located so far is the Daily Advertiser for 1742-1745, which bears Sloane's alphanumeric C 148-153. However, it has been incorporated in the Burney collection of newspapers purchased by the Museum in 1818, and has a Burney shelfmark. Similarly, Sloane's scattered issues of the Jamaica Weekly Courant for 1718 and 1722 have been given numbers within the Burney collection, as has The New-England Courant of 1721-1723, with manuscript notes by Benjamin Franklin.

Ephemera too may have suffered from being lost or discarded either in the moves of Sloane's library, or after receipt by the BM, since many single sheet publications listed in his manuscript catalogue cannot now be found. It is very likely that single sheet items and other ephemera were collected by Sloane over periods of time and kept unbound in bundles or heaps. This type of material was certainly in a vulnerable state. ${ }^{35}$ Even now pamphlets and other slight material kept and bound up by the Bм are frequently found to have grubby first and final leaves, apparently a result of having been unbound and unprotected while in Sloane's possession. Much of his ephemera does survive, often as sole recorded copies, and is now, of course, of considerable bibliographical and historical interest, but a considerable amount appears to have been either lost by accident in the various moves of the collection, or weeded out by the вм.

35 Giles Mandelbrote, 'Sloane and the preservation of printed ephemera', in Mandelbrote and Taylor (eds.), Libraries within the Library, pp. 146-170. 
Sloane had great numbers of academic theses, dissertations or disputations from continental universities, with very significant collections from Leiden and Paris. Most are very slight, about eight pages on average. Some were addressed to Sloane personally by the authors, but many others were acquired by Sloane in bulk purchases or donations, often leaving evidence of previous numberings and owners' markings. This process of acquisition inevitably led to duplication. The 1788 вм sale, as mentioned above, disposed of a number, many were donated to the Bodleian Library, and many cannot now be located. One group in particular is elusive. Throughout the volumes of Lindenius are listed several hundred sixteenth and seventeenth-century single-sheet Paris folio theses, all with the Sloane alphanumeric A 683, acquired in the 1720 s. It is difficult to imagine that such a large body of material would have been simply disposed of by the вм, yet this may be the case, as they have not been located at the BL, and very few copies have been located elsewhere. Only the Bibliothèque Nationale de France and the Bibliothèque Interuniversitaire de Médecine in Paris have any number of these publications.

The number of Sloane printed items classed as 'unlocated', i.e. not found at the $\mathrm{BL}$ and not yet located in other libraries or collections, is growing, as the systematic examination of his catalogues moves forward. At present it looks as though the most numerous type of material classed as unlocated is dissertations and theses, of which Sloane had many duplicates, but this very much reflects the work that has been done in analysing Lindenius, which is rich in this type of publication. The proportion may change as we begin to analyse his other catalogues. It is likely that increasing amounts of more significant material will found to be 'unlocated', particularly natural history books sold as duplicates. Once identified, it should prove relatively easy to find such material in academic libraries, and therefore simpler to locate than the ephemeral thesis literature.

To conclude, we have already found a significant part of Sloane's library, and with time, there is a good chance that the great majority of his books will be located. But what are the purpose and outcomes of this exercise? Why is it of interest to trace the copies owned by Sloane, or indeed any other collector, if we can see what he had by using his catalogue? Does it matter if we cannot find Sloane's own copy of a work which survives in many copies in many libraries? In the case of Sloane's library, the value of this exercise lies partly in completeness: we know that Sloane, for example, owned a copy of Caxton's edition of Chaucer's Canterbury Tales, over a hundred works on gout, and some extremely rare pamphlets in the Basque language, but it is not until the whole library has been identified, and some analysis made of its content, that we can understand how and why such a diverse collection was built up, and what kind of 
reflection it presents of the intellectual environment of the day. Again, put in the context of that environment, the library may shed light on Sloane himself as a scientist and physician. Was he, as was often said even by contemporaries, merely an indiscriminate collector of oddities, or can we see a more systematic and innovative mind at work?

A further reason for reconstituting the library is to understand its role in Sloane's collections as a whole. Books were of course only part of Sloane's collection, but an essential one for his understanding of the specimens and objects he collected. The separation of objects and books, dating back to the foundation of the Museum, is a continuing barrier to understanding how the library supported his scientific investigations in practice. We can get some insight into the way Sloane used printed sources through the Introduction to his Voyage to Jamaica, 1707-1725, where Sloane explains that his work on the identification of plants found in Jamaica was underpinned by searches of classic and modern authorities which he sought out and consulted before reaching conclusions. ${ }^{36}$ His summary of early writers on Jamaica, meticulously collated from printed and manuscript sources, shows very clearly that his library had a dual function, as a collection of objects in its own right, and as an essential tool for his study of his specimens and objects. ${ }^{37}$

The search for authority and evidence also explains his desire, again expressed in the Voyage, to update Lindenius, correcting errors and adding works and editions not listed there, with the addition of medical works in European languages. This would have been a tremendous task, being nothing less than building a complete collection of the medical literature, and was not formally completed, though he was careful to note that through his own collection he had doubled the number of editions listed in Lindenius. ${ }^{38}$ Again, the reconstruction of his library is a prerequisite for the evaluation of Sloane's role as a collector and bibliographer of the literature of medicine.

The physical evidence found in Sloane's own copies, for example marks, manuscript notes and bindings, often reveals traces of their previous ownership and use, and sometimes shows Sloane's intent as a collector. Sloane himself did not often write in his books, but he seems to have valued the manuscript notes of earlier owners. Perhaps the most notable examples of this are his collection of editions of John Ray's Catalogus Plantarum Angliae, 1670 and 1677,

36 Hans Sloane, $A$ voyage to the islands Madera, Barbados, Nieves, S. Christophers and Jamaica (London: Printed by B.M. for the author, 1707-1725), vol. I, 1707, sig. A1-B1.

37 Sloane, Voyage, vol. I, sig. C1-2.

$3^{8}$ Sloane, Voyage, vol. II, sig. a[iii]-a[iv]. 
nearly all of which have manuscript notes by contemporary botanists, ${ }^{39}$ and his 15 copies of 7 editions of the Pharmacopoeia Londinensis published by the Royal College of Physicians, 12 of which contain manuscript notes. Physical evidence such as manuscript notes helps us understand what type of knowledge was valued by the collector, and has the further benefit of shedding light on other dispersed collections. By recording evidence of ownership and the presence of manuscript notes, the SP BC not only illuminates Sloane as a scientist and collector, but also brings to light many otherwise lost libraries, many of which can no longer be reassembled, even virtually, whose remnants have ended up in this great national collection.

In order to assess Sloane's achievements as a physician and a scientist, therefore, we should evaluate his collection of supporting literature. In assessing his achievements as a book collector and as a bibliographer of medicine, we should examine the collection and the collecting methodology. In both cases, we can only assess these achievements by knowing as much as we can of what he used or possessed. We could then say how successful Sloane was in collecting medical literature, and how authoritative his own scientific writings were, how informed his medical practice was, and on what research they were based.

Sloane's library itself is no longer 'lost', but many individual items known to have been owned by Sloane are currently unlocated. There may be lost books, and Sloane's copies may be lost, but as the Sloane project progresses, the number is likely to diminish significantly. This library was remarkable in his time for its size and diversity, and its strengths in medicine and natural history. It contained great treasures and supported the equally significant collections of specimens and objects. It is just as remarkable now, yet for many years it went almost unrecognised. We are fortunate that the library of such an eminent and influential person survives to the extent that it does, and should recognise its significance and its potential as a resource for research into intellectual history, the history of libraries and the history of collections. 